\title{
THE MODEL FOR EVALUATING THE CRITERIA DESCRIBING THE QUALITY OF THE TRIP BY INTERNATIONAL TRAIN
}

\author{
Lijana MASKELIŪNAITĖ, Henrikas SIVILEVIČIUS \\ Department of Transport Technological Equipment, Vilnius Gediminas Technical University, \\ Plytines g. 27, LT-10105 Vilnius, Lithuania
}

Received 31 December 2013; accepted 11 January 2014

\begin{abstract}
The quality of multifaceted objects or phenomena can be hardly described or evaluated by a single criterion. The quality of the trip by train is described by a set of quantitative and qualitative criteria. The influence of all the criteria on the trip by international train may be evaluated by a comprehensive quality index (CQI) or quality index $K$. An additive model is offered for calculating CQI, which consists of the average weights of the criterion groups, as well as normalized weights and variables of the criteria, showing the correspondence of the real value of each criterion to the best, critical or allowable value. A mathematical model, which may be used for determining the quality of the trip by train based on the criteria describing the elements of the train and technical state of the railway track is also presented. Based on the use of 16 criteria describing the elements of the train and the parameters and the technical state of the railway track, the quantitative estimate $K_{A}$ (multiple criteria index) is obtained. The suggested model and the techniques used in the work may be applied to determining the quality or effectiveness of other objects or processes, which can be described by sets of criteria.
\end{abstract}

Keywords: international train, passenger transportation, comprehensive quality index (CQI), evaluation, trip quality, expert research, MCDM, additive model, weight.

JEL Classification: CO2, R4, L62, L92.

\section{Introduction}

In the new age of railway transportation, the main task is to ensure a safe use of railway infrastructure, which should meet the requirements of safety standards (Rao, Tsai 2007). To ensure railway traffic safety, the systems of the railway track and train control, as well as signalling and communication systems, were introduced into railways (Hamilton et al. 2009), and the impact of track parameters and trains on the railway track safety was in-

Corresponding author Henrikas Sivilevičius

E-mail: henrikas.sivilevicius@vgtu.lt 
vestigated (Cherkashin, Pogorelov 2010). It was found that the main factors having a negative effect on railway traffic safety are rail roughness and longitudinal forces acting on the train. The article of Jafarian and Rezvani (2012) presents a comprehensive and transparent study on the evaluation of the railway safety risks using the fuzzy fault tree analysis (FTA). For this purpose, a method for quantification and evaluation of the fault tree in the fuzzy environment is proposed. The method that is presented in this article is based on modifying the weighted averaging according to the levels of defuzzification method. The main results obtained in investigating the impact of the train and railway parameters on the wearing of wheels and rails and their analysis were presented in (Zakharov, Romen 2010; Zakharov et al. 2010). The models for evaluating operational characteristics of the track bed (under the moving load) were created and the spectral analysis of soil acceleration (driving resistance) (Ho et al. 2009) was performed. The calculations of the effect produced on the railway track by various types of trains moving on the straight and curved road sections at various speed (Gorbunov 2010) and the evaluation of geometric railway track parameters were made by using the satellite systems (Koc 2012). The algorithm for calculating the dynamic loads was also developed. The largest displacement of the two-dimensional rail system acted upon by the exciting dynamic force was $22 \mathrm{~mm}$. A slight non-linearity of the considered elastic-plastic material was observed (Noorzaei et al. 2012). Other researchers considered traffic capacity (Ramunas et al. 2011) and the reliability factor of railways (Ivnitsky, Polyakova 2011). The formula for determining the dynamic coefficient, which may serve as a technical basis for designing and assessing the bridges included in the urban railway system, was offered (He et al. 2011), and the dynamic pressure caused by a train running over the Qinghai-Tibet railway embankment located in a permafrost area was investigated (Zhu et al. 2011). A set of programmes most suitable for ensuring railway track safety (Vale et al. 2012) and the models for maintaining the railway and the ballast (Burrow et al. 2009; Sevi, Ge 2012; Lobo-Guerrero, Vallejo 2006) were offered. Now, when the prices of oil, electricity and gas are constantly growing, the methods of saving power and fuel should be sought. The investments in technological, technical and organizational measures, helping to achieve this, and the improvements in management and use of resources are made. Macroeconomic evaluation of the development of transport infrastructure was also performed (Macheret et al. 2010), and the main problems were identified (Walker et al. 2008). A program, helping to find the best vertical layout for a track with a given horizontal layout, was presented (Bababeik, Monajjem 2012). A bottleneck optimization model for increasing the carrying capacity by reasonably arranging routes and turnouts and considering proportionality and minimization of the total occupation time was offered (Liujiang et al. 2012).

In recent years, transport problems have been solved based on the results obtained in scientific research and the recommendations provided by researchers (Gould, Niemeier 2009). The analysis of the automatic clutch durability in locomotives (Daunys et al. 2009) and reconditioning methods of the roll surface of the wheels was performed (Vorobyev et al. 2011). Multicriteria decision making methods were widely used for evaluating the available alternatives and choosing the best option in various technological and management areas, as well as for assessing risks in construction projects (Zavadskas et al. 2010; Liou, Tzeng 2012). 
To improve technical and economic indicators of passenger transportation, the methods of passenger flow prediction and the regression analysis should be implemented by using the automatic control system Express. Using these methods, it will be possible to plan the volumes of passenger transportation and the number of the required trains. Effective planning means $10-15 \%$ decrease in the mileage of trains with unoccupied berths, higher quality of services provided to passengers and lower expenses due to timely formation of the additional trains (Makarova et al. 2011). Rail passenger transportation at a reasonable price is usually unprofitable for the state. Therefore, the aim is to avoid losses. To optimize the process of passenger transportation, various calculations are used, energy consumption for washing, cleaning and disinfection of uniforms, bedclothes, etc., at the railway enterprise laundries, a disinfection chamber and drycleaners is reduced (Finichenko 2011), and the number of trains in the sector of passenger transportation is planned (Dailydka 2010). The evaluation of technological, economic, safety and quality criteria of passenger transportation on an international route was also performed by expert methods (Maskeliūnaite, Sivilevičius 2012). The lack of the data for evaluating passenger transportation quality on this route encouraged the authors (Sivilevičius et al. 2012) to develop a quantitative method and the $K$ index, which allowed them to objectively assess the considered passenger transportation quality and to express it by a single value.

The aim of the present paper is to suggest an original mathematical model for evaluating the significance of 16 criteria describing the train elements and the technical state of rails (railway track), as well as their significance to the comprehensive quality index (CQI), and to validate the results by considering a numerical example of comprehensive quality index calculation for the international train 'Vilnius-Moscow'.

\section{A description of the activities of the joint-stock company Lietuvos geležinkeliai}

In the Baltic States, the distance between the rails of a railway, the track gauge, is of the Russian standard, making $1520 \mathrm{~mm}$. There is no special high-speed railway in Lithuania, which means that the passenger and freight trains use the same railway tracks. At present, the highest allowable speed of passenger trains in Lithuania reaches $120 \mathrm{~km} / \mathrm{h}$ on some routes. The renewal of the infrastructure could allow the speed of passenger trains to be increased up to $160 \mathrm{~km} / \mathrm{h}$ on some railway sections. The Baltic states, including Lithuania, Estonia and Latvia, are interested in the construction of the railway tracks with the European gauge of (1435 mm). Visiting Lithuania, Toomas Hendrik Ilves, the President of Estonia, expressed his regret about the absence of a high-speed train running between Vilnius and Tallinn, and the high-speed railway with the terminals in Helsinki in the North and in Berlin in the West. He also expressed his hope that this is only the question of time, when this railway will appear (Estijos prezidentas siūlo... 2013).

'Rail Baltica' is the railway line of the European standard, with the design speed of the trains reaching $240 \mathrm{~km} / \mathrm{h}$. The AB 'Lietuvos geležinkeliai' (joint-stock company 'Lithuanian Railways') company is the performer of this EU TEN-T priority project. The project 'Rail Baltica' is aimed at developing the East-West railway transportation system providing the 
connection of the Baltic States with Poland and through it with the other European countries and their railway network (Lithuanian Railway 2012). In Lithuania, 7 km-long railway with the European track gauge, connecting Mockava and Šeštokai has already been constructed. In May 2013, the reconstruction of the track section from the frontier with Poland to Mockava has been started. The construction of the $120 \mathrm{~km}$-long railway section of the European track gauge leading to Kaunas is planned to be completed in 2015. 'Rail Baltica' will provide the shortest route for passengers to reach the Baltic states as well as West European countries safely and comfortably. It will also allow Lithuania to increase freight transportation from and to other countries and, thereby, to increase the competitiveness of the state.

The development of railway transport in Lithuania is closely connected with the realization of new initiatives of the European Union, pursuing the policy of sustainable transport development. Passenger transportation still faces some unsolved problems, though positive results achieved in 2011, e.g. the increased number of passengers (Fig. 1) and considerably reduced losses in passenger transportation, encourage investments in rolling stock renewal and other initiatives aimed at making transportation by railway more attractive to passengers. The number of passengers has considerably increased on the routes Vilnius-Kaunas, Vilnius-Klaipeda and Vilnius-Minsk. On the latter route, 191 thous. passengers were transported during the nine months in 2012 compared to 171 thous. in the year 2011 . The electrification works have been started on the route Naujoji Vilnia-Kena. The route Vilnius-Minsk will be electrified by 2014 and new electric trains will run there. This will allow passengers to cover the distance between these two cities in two hours without stopping if the formalities at the customs of the two states could be quickly settled. In its turn, this would give the railway transport a great competitive advantage over the automobile transport, which cannot cover this distance so quickly (Saladžius 2012).

The AB 'Lietuvos geležinkeliai' is important for the development of the economy ofLithuania (Fig. 2).

In 2012, the 'GILD Bankers' investment bank published a list of 100 most highly valued Lithuanian companies in the year 2011, and AB 'Lietuvos geležinkeliai' was at the top of it. The leaders managed to increase their value from 2.678 billion Lt to 3.024 billion Lt during a year. The financial indicators of the company were also improved considerably (Saladžius 2012).

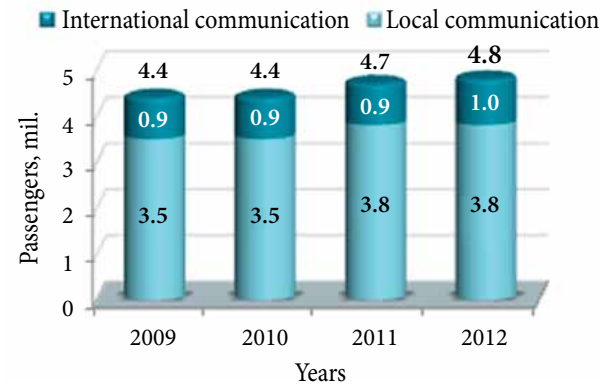

Fig. 1 . The dynamics of passenger flows in 2009-2012 (mil)

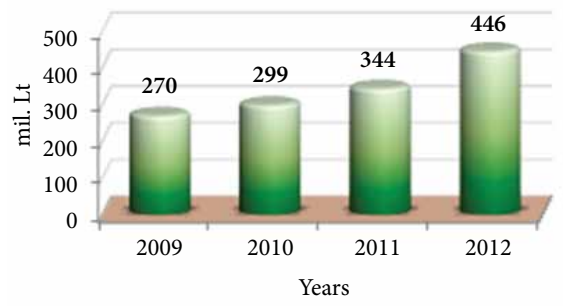

Fig. 2. The payments of the $A B$ 'Lietuvos geležinkeliai' to the budgets of the state, municipality and 'Sodra' (State Social Insurance Fund Board under the Ministry of Social Security and Labour) and other financial contributions to the state economy in 2009-2012 (million Lt) 


\section{The development and description of the model of travel by train}

The quality of travel by train (QTT) is described by both qualitative and quantitative criteria. It would be convenient to quantitatively evaluate the significance of all the criteria for QTT by a single number. The significance of particular criteria differs to some extent. In the work (Maskeliūnaite et al. 2009), 49 QTT criteria belonging to four various groups A, B, C, D (Fig. 3) are considered. Their average weights are determined by using the expert evaluation method.

\begin{tabular}{|l|} 
THE CRITERIA OF RAILWAY TRIP QUALITY \\
A. The criteria describing the train elements and the technical state of the railway track \\
B. The criteria describing planning and technology of the railway trip (Sivilevičius et al. 2012) \\
C. The criteria describing the cost of the trip and the provided services \\
D. The criteria describing railway trip safety
\end{tabular}

A1. Quality of the railway track

A2. Speed of the train (trip duration)

A3. The state of the carriage exterior (cleanness, deformat ions, damage, etc.)

A4. Noise reduction measures (noise insulation)

A5. The interior of a passenger carriage

A6. Operation of ventilation, air conditioning, cooling and lighting systems in terms of their timely switching on/off

A7. Temperature requiredinside a passenger carriage

A8. Type (simple or vacuum) and condition of toilets (lavatories)

A9. Construction of berths (safety belts on upper level berths), special facilities for the disabled

A10. Availability of regularly operating shower

A11. Special compartments for transporting bigcles

A12. Smoking places

A13. Radio broadcasting unit and its centralized operation (switching on/off)

A14. Dining-car (buffet-car)

A15. Possibility of calling an attendant to a passengers' compartment in emergency cases

A16. Possibility of using electrical appliances (hairdryer, iron, etc.)

Fig. 3. A diagram of quality criteria groups $A, B, C, D$, describing the railway trip quality 
The weights of 16 criteria, belonging to group A, and describing the train elements and technical state of rails (railway track), were obtained from the survey of experts, when three categories of respondents - passengers $(\mathrm{P})$ and experts, including the service staff of the train (ST) and the administration staff (AS) of the joint-stock company (JSC) 'Lithuanian Railways' ( $A B$ „Lietuvos geležinkeliai“), gave their opinions.

Trains made up for various routes have railway carriages of different types and technical state and are serviced by the staff members who have different work experience and education. The quality of passenger transportation by any train can be determined only roughly, subjectively and intuitively. Therefore, to evaluate it more accurately, a quantitative method and the index $K$, allowing the quality of travel on a particular route to be expressed by a single number, were developed. The index $K$ is calculated by the equation:

$$
K=K_{A}+K_{B}+K_{C}+K_{D}
$$

where $K_{A}, K_{B}, K_{C}, K_{D}$ denote CQI of the criteria of the groups A, B, C and D, describing the quality of travel by an international train.

The model for calculating the criteria, describing the train elements and technical state of the railway track based on the mean weight coefficient $\bar{Z}_{A}^{*}$ and the mean weight of each criterion (expressing the estimates of the significance of group A criteria, elicited from all three categories of respondents and experts) is determined by the equation:

$$
K_{A}=\bar{Z}_{A}^{*} \cdot\left(\bar{Q}_{A 1} \cdot x_{A 1}+\bar{Q}_{A 2} \cdot x_{A 2}+\ldots+\bar{Q}_{A 16} \cdot x_{A 16}\right),
$$

where $K_{A}$ is a comprehensive quality index (CQI) of the international train (ranging from 0 to 1$) ; \bar{Z}_{A}^{*}$ is the mean weight, reflecting the respondents' and experts' estimates of the significance of the criteria of group $A ; \bar{Q}_{A 1}, \ldots, \bar{Q}_{A m}$ denote the mean weight values of $j$-th criterion of group $\mathrm{A}(1, \ldots, m)$ determined by the expert evaluation method (Sivilevičius, Maskeliūnaite 2010; Maskeliunaitè, Sivilevicius 2011); $x_{A 1}, \ldots, x_{A m}$ are the variables of $j$-th criterion of group $\mathrm{A}(1, \ldots, m)$, whose estimates are used for determining the real criterion value, ranging from 0 to 1 .

The mean weight $\bar{Z}_{A}^{*}$ shows the significance of the criteria of group A (when the number of the respondents and experts in each category differs). This weight is calculated as follows:

$$
\bar{Z}_{A}^{*}=\frac{Z_{A, P} \cdot n_{P}+Z_{A, S T} \cdot n_{S T}+Z_{A, A S} \cdot n_{A S}}{n_{P}+n_{S T}+n_{A S}},
$$

where $Z_{A, P}, Z_{A, S T}, Z_{A, A S}$ are weights given to the criteria of group A by the respondents (experts) of categories $\mathrm{P}, \mathrm{ST}, \mathrm{AS} ; n_{P}, n_{S T}, n_{A S}$ denote the numbers of the respondents (P) and experts (ST, AS).

The significance estimates (in points) assigned to the criteria of group A by passengers $(\mathrm{P})$, service staff of the train (ST) and the administration staff (AS) are presented in Table 1. 
Table 1. The significance (weight) of the criteria of group A describing travel by train

\begin{tabular}{lcc}
\hline \multicolumn{1}{c}{ Category of respondents and experts } & Number of questionnaires & Weight \\
\hline Passengers (P) & 21 & $Z_{A, P}=0.2143$ \\
\hline Service staff of the train (ST) & 20 & $Z_{A, S T}=0.2800$ \\
\hline $\begin{array}{l}\text { Administration staff of Joint-Stock Company } \\
\text { 'Lithuanian Railways' (AS) }\end{array}$ & 9 & $Z_{A, A S}=0.1444$ \\
\hline $\begin{array}{l}\text { The average estimate value of all respondents } \\
\text { and experts in their categories }\end{array}$ & 50 & $\bar{Z}_{A}^{*}=0.228$ \\
\hline
\end{tabular}

It has been obtained (equation 3 ) that the average weight for the opinions of respondents and experts, regarding the significance of the criteria of group $\mathrm{A}$, is $\bar{Z}_{A}^{*}=0.228$.

\section{The model for evaluating the criteria describing the technical state of the railway track and the elements of the train}

To calculate the CQI, showing the significance of the train elements and technical state of rails (railway track), the variables of any criterion $x_{A 1}, \ldots, x_{A 16}$, serving as a basis for calculating the real criterion value (which ranges from 0 to 1 ), should be determined.

Quality of the railway track. Geometrical parameters of the railway track include the gauge, rail dents, the position of rails in plan and elevation view and misalignments. Track quality index (TQI), allowing us to observe the changes in geometrical track parameters, is used to describe track quality. The total TQI value is calculated for each kilometre of the railway track by summing up the TQI values of the geometrical railway track parameter. The total TQI, describing the quality of the considered railway track in terms varying from 'very good' to 'poor', may range from 0 to 45 and more points (Table 2) (Savaeigio kelio matavimo vagono EM-140... 2012). When the estimate value of the railway track quality decreases, the train speed is also decreased. The account of TQI is provided by the track geometry car (TGC) program EMGraph. It consists of the considered railway track, as well as the considered parameters and their values.

The condition (state) of the railway track may be described by seven geometrical parameters (criteria), including gauge (1), cross level (2), left and right surfaces $(3,4)$, left and right alignment $(5,6)$ and twist $(7)$. All these parameters are measured in millimetres. Their values for $1 \mathrm{~km}$ and the total track length vary, i.e. are characterized by variation (spread). The higher the variation, the larger the deviation of each particular geometrical parameter's values from the nominal (specified) values and the closer they approach critical values. This increases the possibility of an accident, e.g. the train (or its cars) derailing. High variation of geometrical track parameters gives rise to faster wearing of rails and wheelsets and increases railway car vibration, noise and acceleration, thereby decreasing the level of comfort for passengers and the quality of travel by train.

The variation of each geometrical parameter of the railway track on each $1 \mathrm{~km}$-long track section is measured by a mobile laboratory, i.e. a track geometry car. The total of the variations of all 7 parameters shows the technical condition of the track expressed by track quality 
index, TQI. The smaller the real TQI $I_{f}$ value, the higher the track quality. In the Instruction K/259 self-propelled track geometry car EM-140 (Savaeigio kelio matavimo... 2012), issued by order of the director of $\mathrm{AB}$ 'Lietuvos geležinkeliai', four levels of track quality (ranging from very good to poor), which correspond to various $T Q I_{n o r m}$ values, have been specified (Table 2).

Table 2. Qualitative evaluation of track based on $T Q I_{\text {norm }}$ values

\begin{tabular}{cc}
\hline Total TQI & Track \\
\hline $0-20$ & Very good \\
\hline $21-34$ & Good \\
\hline $35-44$ & Satisfactory \\
\hline$\geq 45$ & Poor \\
\hline
\end{tabular}

The intervals of track quality levels based on non-dimensional TQI ${ }_{\text {norm }}$ values, as specified by the Instruction K/259, (Savaeigio kelio matavimo... 2012) differ to various extent. Thus, for 'very good' (quality), the difference is 20 (20-0), for 'good', the difference is 13 (34-21), for 'satisfactory' - 9 (44-35) and for 'poor', the difference is not clear because TQI ${ }_{\text {norm }} \geq 45$. Table 2 does not show to what poor track state the TQI value can grow. The experimental investigation performed by the authors of the present work has shown that the highest real $T Q I_{\text {fmax }}$ value for $1 \mathrm{~km}$ track is 92.4 , while the lowest $T Q I_{\text {fmin }}$ value is equal to 7.49.

The Instruction K/259 of Track geometry car EM-140 (Savaeigio kelio matavimo... 2012) erroneously states that TQI is a non-dimensional value, showing gauge deviation. Since all geometrical parameters of the track are measured in millimetres $(\mathrm{mm})$, their total, making the TQI value, also has a dimension. The article by Xu et al. (2011), presenting the modelling of the track quality index, states that the method used in China for defining TQI is based on the total of seven standard deviations (TQI $=\sum_{g=1}^{7} \sigma_{\dot{g}}$, where $g=1,2, \ldots, 7$ denotes the number of the parameter), given in $\mathrm{mm}$. In this work, the variation of any geometrical parameter (including gauge, cross level, left and right surface, left and right alignment, and twist) is expressed by the standard deviation $\sigma_{\dot{g}}$. The authors think, however, that to sum up standard deviations according to mathematical rules is not correct. In this case, it is more appropriate to use variances $\sigma_{\dot{g}}^{2}$.

It is also hardly possible to understand whether $\sigma_{\dot{g}}$ is the spread measure of a geometrical track parameter used in the work (Xu et al. 2011), if a graphical standard deviation model with the curve of probability density for normal or lognormal distribution is not given. We think that the TQI coefficient is the sum of variances $\sigma_{\dot{g}}^{2}$ of individual geometrical track parameters, expressed in $\mathrm{mm}^{2}$.

In the absence of the highest fixed $T Q I_{\max }$ value, or $T Q I_{\text {rib }}$ value (which means that trains are not allowed to run even at the lowest speed), it is hardly possible to calculate the variable $x_{A 1}^{\prime}$ of the first group $A$ criterion based on the relationship between the values of $T Q I_{f}$ and $T Q I_{\max }$ or $T Q I_{\text {rib }}$ subtracted from one.

Given that the track with $x_{A 1}^{\prime}=1$ for each $1 \mathrm{~km}$ track length is the best, while the track with $x_{A 1}^{\prime}=0$ is the worst, and the specified quantitative variation of its quality 
is uniform (making 0.25), the third power regression equation (4), defining non-linear dependence of $x_{A 1}^{\prime}$ on $T Q I_{n o r m}$, has been solved and the curve has been plotted (see Fig. 4).

$$
x_{A 1}^{\prime}=-3 \cdot 10^{-6} \cdot \mathrm{TQI}_{\text {norm }}{ }^{3}-2 \cdot 10^{-5} \cdot \mathrm{TQI}_{\text {norm }}{ }^{2}-0.0106 \cdot \mathrm{TQI} \mathrm{Iorm}+0.9999 .
$$

The relationship close to the functional dependence between the standard track quality index $T Q I_{n o r m}$ determined by the track geometry car and variable $x_{A 1}^{\prime}$ of the first criterion of group $A$, whose determination coefficient $R^{2}=0.9984$, has been found.

The value of $T Q I_{n o r m}$, corresponding to $x_{A 1}^{\prime}=0$, which was obtained by using the equation (4), reached about 51-52 $\mathrm{mm}^{2}$. For the real track of very poor quality, this value may be several times larger. Given that $x_{A 1}^{\prime}$ values cannot be negative, and the real $T Q I_{f}$, determined by a track geometry car may exceed $52 \mathrm{~mm}^{2}$, four additional points, extending the area of poor track quality TQI from 45 to 90, have been introduced (see Fig. 4).

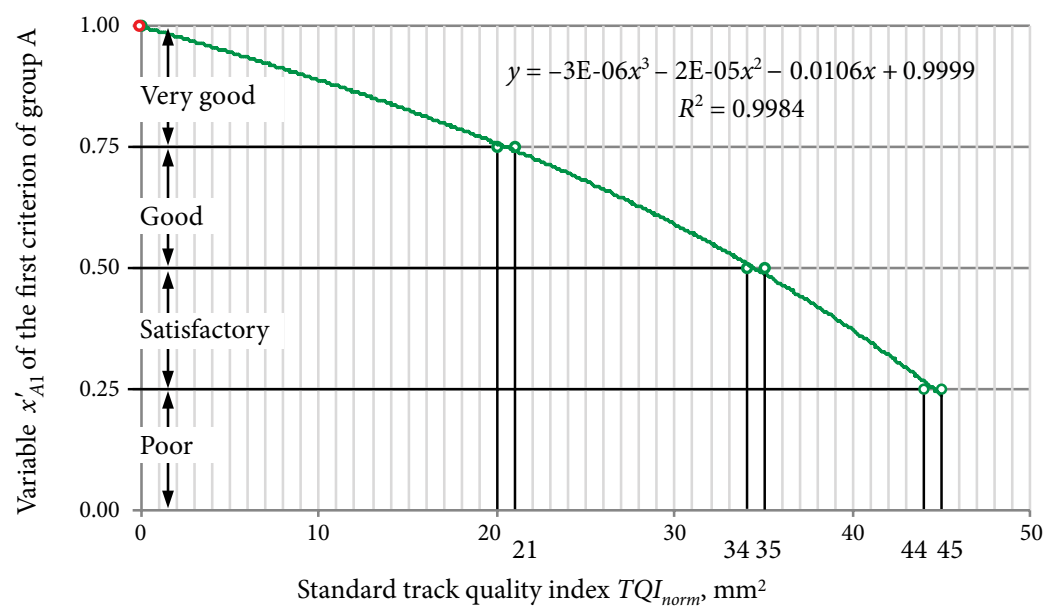

Fig. 4. The relationship between the variable $x_{A 1}^{\prime}$ of the first group $A$ criterion describing the dependence of the railway trip quality on the railway track condition and TQI $I_{\text {norm }}$

The increase of TQI values from $60 \mathrm{~mm}^{2}$ to $90 \mathrm{~mm}^{2}$ by the $10 \mathrm{~mm}^{2}$ step caused the decrease of $x_{A 1}^{\prime}$ values (solid points) so that the curve of the function $x_{A 1}^{\prime}=f(T Q I)$ could run smoothly from $T Q I_{n o r m}=0$, when $x_{A 1}^{\prime}=1$, through all standard $T Q I_{\text {norm }}$ values, and asymptotically approach $x_{A 1}^{\prime}=0$. The standardized $T Q I_{n o r m}$ values and the modelled $T Q I_{\text {mod }}$ values (solid points) were described by various regression equations, such as linear $\left(y_{1}\right)$, quadratic $\left(y_{2}\right)$, cubic $\left(y_{3}\right)$ and fourth power $\left(y_{4}\right)$ regression equations (see Fig. 5).

Determination coefficients of regression equations $R^{2}$ (Fig. 5) increase with the increase in the equation power. Determination coefficient of the fourth power regression equation is $R^{2}=0.9961$, while its regression coefficients of higher accuracy for $T Q I_{f s}$ allow us to obtain the final expression, showing how the real quality index $T Q I_{f s}$ of the $s$-th track section is related to the variable $x_{A 1}^{\prime}$, showing the quality of this track:

$$
x_{A 1}^{\prime}=0.997+0.00245 \cdot T Q I_{f_{s}}-0.000962 \cdot \mathrm{TQI}_{f_{s}}^{2}+1.532 \cdot 10^{-5} \cdot \mathrm{TQI}_{f_{s}}^{3}-6.99 \cdot 10^{-8} \cdot \mathrm{TQI}_{f_{s}}^{4} \text {. }
$$




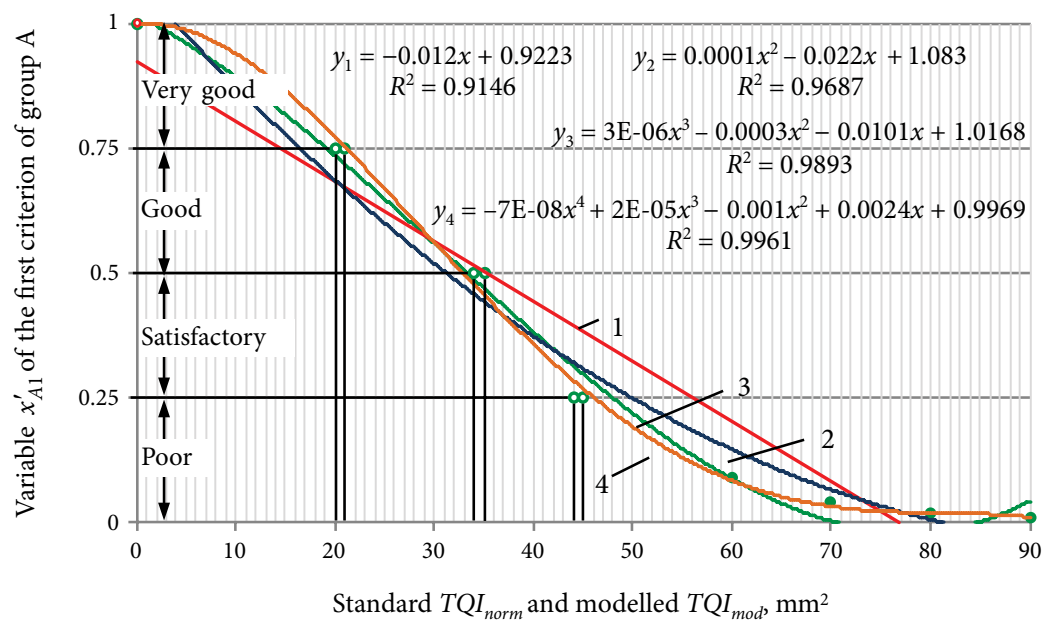

Fig. 5. Various regression equations describing the values of standard track quality index $T Q I_{\text {norm }}$ and modelled $T Q I_{\text {mod }}$

The curve (Fig. 6) obtained based on the regression equation (5) does not completely comply with some standard TQI $I_{\text {norm }}$ values. The smallest $x_{A 1}^{\prime}$ value, which is $x_{A 1}^{\prime}=0.5$, corresponds to $T Q I_{f s} \approx 33 \mathrm{~mm}^{2}$ (see $T Q I_{\text {norm }}=34 \mathrm{~mm}^{2}$ in Table 2 and Fig. 6), while the largest poor quality track value $x_{A 1}^{\prime}=0.25$ corresponds to $T Q I_{f s} \approx 46 \mathrm{~mm}^{2}\left(T Q I_{n o r m}=45 \mathrm{~mm}^{2}\right.$ in Table 2 and Fig. 6). Some limiting standard values of various track quality levels, which are used now, could be slightly corrected because they are conditional and do not reflect the essential parameters determining comfort of travel by train for passengers as well as limiting acceleration values, accident risk, etc.

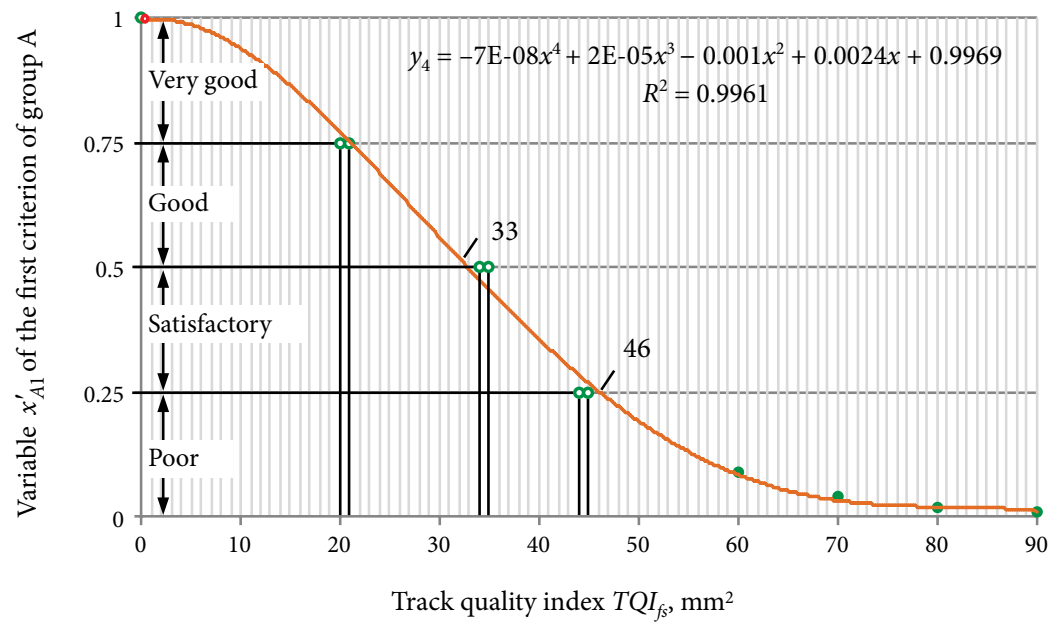

Fig. 6. The regression equation and the curve used for determining $x_{A 1}^{\prime}$ value for the first criterion of group A, when the real TQIfs is given 
The railway track is the total of all $s$-th kilometre lengths with various $T Q I_{f s}$ values determined by a geometry car. Therefore, the quality of the whole track may be determined in terms of the compliance of the average $\overline{T Q I}_{f}$ for its particular $1 \mathrm{~km}$ lengths with the variable $x_{A 1}$ of the first criterion of group $A$ obtained from the equation (5) or the curve (Fig. 6). In the regression equation, the average value of one-kilometre track lengths is used instead of $T Q I_{f}$ :

$$
\overline{T Q I}_{f}=\frac{\sum_{s=1}^{N_{k m}} T Q I_{f s}}{N_{k m}},
$$

where $\overline{T Q I}_{f}$ is the average track quality index, whose numerical value is equal to the total variance $\sigma_{b}^{2}, \mathrm{~mm}^{2}$; $\overline{T Q I}_{f s}$ is quality index of $s$-th one-kilometre track length, whose numerical value is equal to the total variance of the particular $g$-th geometrical parameters $\sigma_{g}^{2}$, $s=1,2, \ldots, N_{k m}, \mathrm{~mm}^{2}$ and $N_{k m}$ is the track length, $\mathrm{km}$.

Thus, track quality is shown by the compliance of the variable $x_{A 1}$ of the first criterion of group A, which was calculated from formula (7) having the average $\overline{T Q I}_{f}$, with one of the standard quality levels (very good, good, satisfactory, poor) given in Table 2.

$$
\begin{gathered}
x_{A 1}=0.997+0.00245 \cdot \frac{\sum_{s=1}^{N_{k m}} T Q I_{f s}}{N_{k m}}-0.000962 \cdot\left(\frac{\sum_{s=1}^{N_{k m}} T Q I_{f s}}{N_{k m}}\right)^{2}+1.532 \cdot 10^{-5} \cdot\left(\frac{\sum_{s=1}^{N_{k m}} T Q I_{f s}}{N_{k m}}\right)^{3}- \\
6.99 \cdot 10^{-8} \cdot\left(\frac{\sum_{s=1}^{N_{k m}} T Q I_{f s}}{N_{k m}}\right)^{4} .
\end{gathered}
$$

The total track variance $\sigma_{b}^{2}$ for all seven geometrical parameters (their variances denoted as $\left.\sigma_{g}^{2}, g=1,2, \ldots, 7\right)$, measured by a geometry car, is used as TQI, based on which $x_{A 1}$ is calculated. The value of $x_{A 1}$ obtained from the regression equation (7) is used in the model (2) to evaluate the quality of travel by train, depending on the railway track quality.

Speed of the train (trip duration). To ensure safe traffic by railway, taking into account the surface railway structures, earth embankments, their condition and various types of trains, as well as their working to schedule and meeting technical regulations of railway operation, the highest allowable speed of trains and locomotives on the railway tracks near the stations and on the railway track sections between stations (Dèl didžiausio leistino traukinių ir lokomotyvų greičio... 2009; Techninio geležinkelių naudojimo nuostatai 1996) was specified. The value of CQI $K_{A}$ summand, determining the influence of the train speed (time of travel), is calculated by the equation: 


$$
x_{A 2}=\frac{\sum_{l=1}^{n_{\text {stage }}}\left(1-\frac{\left|\Delta v_{f}\right|}{v_{\max , l}}\right) \cdot l_{l}}{\sum_{l=1}^{n_{\text {stage }}} l_{l}},
$$

where $x_{A 2}$ is the variable of the 2 nd criterion of group A; $n_{\text {stage }}$ is the number of railway track sections between stations $\left(l=1,2, \ldots, n_{\text {stage }}\right) ; \Delta v_{f}$ is the real and the highest allowable speed difference of a train at the $l$-th section of the track, $\mathrm{km} / \mathrm{h} ; v_{\max , l}$ is the highest allowable speed of a train at the $l$-th section of the track, $\mathrm{km} / \mathrm{h} ; l_{l}$ denotes the lengths of the sections of the track, $\mathrm{km}$.

The state of the passenger carriage exterior. The condition of the passenger carriage exterior (cleanness, deformations, damages, etc.) is evaluated in points as follows: 0 means that the carriage is not clean and has some deformations or damages; 1 shows that the carriage is not clean, but any deformations or damages cannot be observed, or it is clean, but there are some damages; 2 denotes that the carriage is clean and has no damages. The value of CQI $K_{A}$ summand, determining the influence of the carriage cleanness and damages, is calculated by the equation:

$$
x_{A 3}=\frac{\sum_{c=1}^{n_{c a r}}\left(\frac{C E S_{f}}{C E S_{\max }}\right)_{c}}{n_{c a r}},
$$

where $x_{A 3}$ is the variable of the 3 rd criterion of group A; $C E S_{f}$ is the real condition (cleanness, damages) of the $c$-th carriage $\left(c=1,2, \ldots, n_{c a r}\right)$ expressed in points $\left(0,1\right.$ or 2 points); $C E S_{\max }$ is the highest estimate value of the carriage in points ( 2 points); $n_{c a r}$ is the number of carriages in the train.

Noise reduction measures (noise insulation). The limiting values of noise produced by the stationary noise sources in residential and public buildings and their environment are specified by the hygiene standards. The specified noise level can be equivalent to the noise level in the train conductor's compartment. Limiting noise exposure values are specified by risks regulations (Darbuotojų apsaugos nuo triukšmo... 2005) aimed at protecting the workers from noise exposure. They give noise exposure levels allowable for starting the activities, based on the noise levels recorded daily. The limiting noise exposure value $\mathrm{L}_{\mathrm{EX}}{ }_{\mathrm{gh}}=87 \mathrm{~dB}(\mathrm{~A})$. The CQI $K_{A}$ summand, assessing the effectiveness of measures aimed at decreasing noise level, is calculated by the equation:

$$
x_{A 4}=1-\frac{\sum_{c=1}^{n_{c a r}}\left(\frac{N L_{f}}{N L_{\max , a}}\right)_{c}}{n_{c a r}},
$$

where $x_{A 4}$ is the variable of the 4 th criterion of group A; $N L_{f}$ is the real noise level in the $c$-th carriage, $\mathrm{dBA} ; N L_{\max , a}$ is the allowable noise level in the $c$-th carriage, $\mathrm{dBA}, n_{c a r}$ is the number of carriages in the train. 
The interior of a passenger carriage. This is important because it contributes to creating a favourable impression about the company, providing passenger transportation services. Moreover, pleasant interior finish makes passengers and service staff feel good during the journey. Passenger carriage interior is evaluated in points as follows: 0 is given to an old (not modernized) carriage, 1 is assigned to an old (modernized) carriage and 2 is given to a new carriage. The CQI $K_{A}$ summand, assessing the carriage interior influence on travel quality, is calculated by the equation:

$$
x_{A 5}=\frac{\sum_{c=1}^{n_{c a r}}\left(\frac{C I_{f}}{C I_{\max }}\right)_{c}}{n_{c a r}},
$$

where $x_{A 5}$ is the variable of the 5 th criterion of group A; $C I_{f}$ is the real estimate of the $c$-th carriage interior in points ( 0,1 or 2 points); $C I_{\max }$ is the maximum allowable carriage interior estimate value in points ( 2 points); $n_{c a r}$ is the number of carriages in the train.

Operation of ventilation, air conditioning, cooling and lighting systems in terms of their timely switching on/off. The operation of ventilation, air conditioning, cooling, heating and lighting systems is evaluated in points as follows: 0 means that none of these systems operate in the carriage, 1 shows that one of these systems operates in the carriage, 2 indicates that two systems operate in the carriage, 3 implies that three systems operate in the carriage and 4 means that all the above-mentioned systems operate in the carriage. The CQI $K_{A}$ summand, assessing the influence of carriage ventilation, air conditioning, heating and lighting systems on travel quality, is calculated by the equation:

$$
x_{A 6}=\frac{\sum_{c=1}^{n_{c a r}}\left(\frac{V C L_{f}}{V C L_{\max }}\right)_{c}}{n_{c a r}},
$$

where $x_{A 6}$ is the variable of the 6th criterion of group A; $V C L_{f}$ is the estimate (in points) of the operation of the $c$-th carriage systems $\left(0,1,2,3\right.$ or 4 points ); $V C L_{\max }$ is the highest possible estimate of the systems operating in the carriage ( 4 points); $n_{c a r}$ is the number of carriages in the train.

Temperature required inside a passenger carriage. The water heating system should provide comfortable conditions for passengers and service staff of the train (and of a particular carriage). The air temperature in a passenger carriage should be at least $+18^{\circ} \mathrm{C}$, even when the outdoor temperature reaches $-40{ }^{\circ} \mathrm{C}$. The carriages are heated by burning solid fuel. When the water in the boiler is heated by electric heaters (from the high voltage overhead contact system of $3000 \mathrm{~V}$ ), the temperature in the passenger carriage is automatically maintained in the range of $22 \pm 2{ }^{\circ} \mathrm{C}$. In summer, the temperature is maintained in the range of $24 \pm 2{ }^{\circ} \mathrm{C}$ due to the use of air-conditioning systems. If, in winter, the average real temperature in the carriage is $+22^{\circ} \mathrm{C}$ (Fig. 7), this is considered to correspond to the highest quality level $\left(x_{A 7}=1\right.$ ). When the real temperature is equal to the lowest allowable value of the winter temperature 


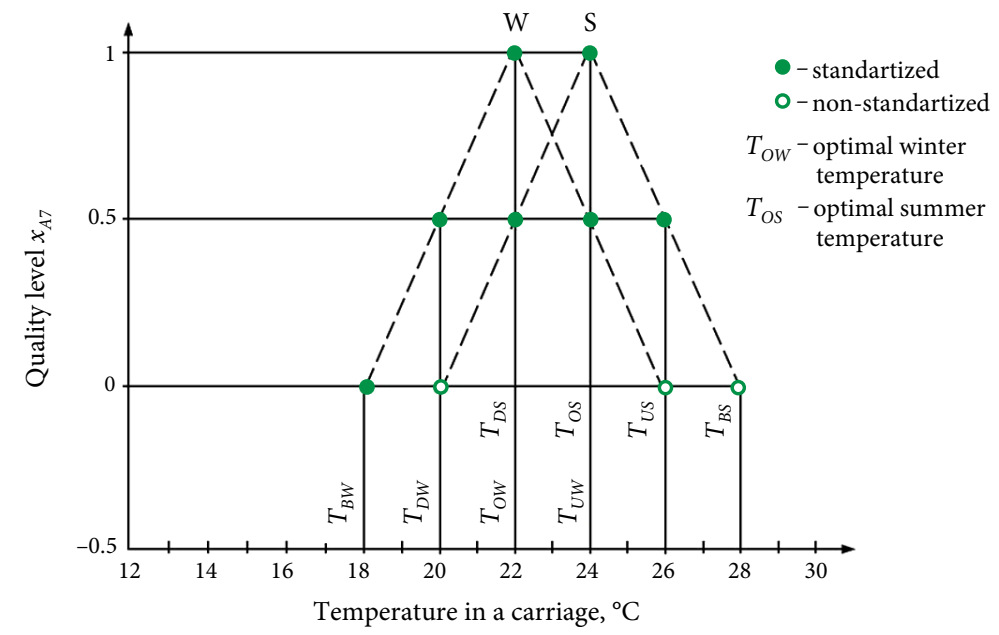

Fig. 7. The relationship between the standardized temperature in a carriage and passenger comfort in winter (when the outdoor temperature is not lower than $-40^{\circ} \mathrm{C}$ ) and in summer (when air conditioning is used)

$T_{D W}=+20^{\circ} \mathrm{C}$ or to the highest allowable value $T_{U W}=+24^{\circ} \mathrm{C}$, then, $x_{A 7}=0.5$. If, in summer, the average temperature matches the optimal temperature in this season equal to $+24^{\circ} \mathrm{C}$, then, $x_{A 7}=1$. When the real temperature corresponds to the lowest allowable value in summer, $T_{D S}=\bar{T}_{f}=+22^{\circ} \mathrm{C}$, or to the highest allowable temperature value $T_{U S}=\bar{T}_{f}=+26^{\circ} \mathrm{C}$, then, there is the average quality level $\left(x_{A 7}=0.5\right)$ in the carriage. The standards do not regulate the temperature in the carriage higher than $+28^{\circ} \mathrm{C}$ and lower than $+20^{\circ} \mathrm{C}$ in summer and higher than $+26^{\circ} \mathrm{C}$ in winter (Egorov 1987).

The CQI $K_{A}$ summand, assessing the temperature inside the carriage, is calculated by the equation:

$$
x_{A 7}=1-\frac{\sum_{c=1}^{n_{c a r} \mid \frac{T_{U}+T_{D}}{2}-\bar{T}_{f}} \frac{T_{U}-T_{D}}{n_{c a r}}}{n_{c}},
$$

where $T_{D}$ is the lowest allowable carriage temperature, ${ }^{\circ} \mathrm{C}$. In winter, when solid fuel is burned and the outdoor temperature is not lower than $-40^{\circ} \mathrm{C}$ and not higher than $+10^{\circ} \mathrm{C}, T_{D}=18^{\circ} \mathrm{C}$, while when water is heated by electricity, $T_{D}=20^{\circ} \mathrm{C}$ (the temperature of $(22 \pm 2)^{\circ} \mathrm{C}$ should be automatically maintained). In summer, when air-conditioning is used, the temperature of $(24 \pm 2)^{\circ} \mathrm{C}$ should be automatically maintained, therefore, $T_{D}=22^{\circ} \mathrm{C}$ (Egorov 1987); $T_{U}$ is the highest allowable temperature inside a passenger carriage $\left(+26^{\circ} \mathrm{C}\right)$. In winter, when the outdoor temperature is not lower than $-40^{\circ} \mathrm{C}$ and solid fuel is used for heating, $T_{U}=+22^{\circ} \mathrm{C}$, while when water is heated by electricity, $T_{U}=24^{\circ} \mathrm{C}$ (the temperature of $(22 \pm 2)^{\circ} \mathrm{C}$ should be automatically maintained); $n_{\text {car }}$ is the number of passenger carriages in the train; $\bar{T}_{f}$ is the 
average temperature in the $c$-th carriage measured $n_{T}$ times at various places of the carriage during the trip:

$$
\bar{T}_{f}=\frac{\sum_{t=1}^{n_{T}} T_{f t}}{n_{T}},
$$

where $T_{f t}$ is the temperature obtained in the $t$-th measurement, ${ }^{\circ} \mathrm{C} ; n_{T}$ is the number of temperature measurements $\left(t=1,2, \ldots, n_{T}\right)$.

The worst case $\left(x_{A 7}=0\right)$ can be observed, when $\bar{T}_{f}$ is by $2{ }^{\circ} \mathrm{C}$ smaller than the lowest allowable value $T_{D}$ or when $\bar{T}_{f}$ is by $2{ }^{\circ} \mathrm{C}$ larger than the highest allowable value $T_{U}$. If $\bar{T}_{f}$ is smaller than $T_{D}$ by more than $2{ }^{\circ} \mathrm{C}$ or is by $2^{\circ} \mathrm{C}$ larger than $T_{U}$, a negative value of $x_{A 7}$ is obtained, which is taken to be equal to zero.

Type (ordinary or vacuum) and condition of the train toilets (lavatories). In the carriages of long-distance and local passenger trains, two vacuum toilets (lavatories) should be equipped, while one toilet should be provided in the luggage car and one in the dining car.

A toilet (lavatory or WC) is evaluated in points as follows: 0 means that toilets (lavatories) in a passenger carriage are out of order, 1 shows that there are ordinary toilets in the carriage, which are clean and in good order, 2 shows that, in a passenger carriage, there is one ordinary toilet and one vacuum toilet, which are clean and in good order, 3 implies that there are vacuum toilets in the carriage, but they are not clean and not in good order, 4 means that there are vacuum toilets in the carriage, which are clean and in good order. The CQI $K_{A}$ summand, assessing the influence of passenger carriage's toilets on the trip quality, is calculated by the equation:

$$
x_{A 8}=\frac{\sum_{c=1}^{n_{c a r}}\left(\frac{W C_{f}}{W C_{\max }}\right)_{c}}{n_{c a r}},
$$

where $x_{A 8}$ is the variable of the 8th criterion of group A; $W C_{f}$ is the estimate of the real condition of lavatories in the $c$-th carriage, expressed in points $\left(0,1,2,3\right.$ or 4 points); $W C_{\max }$ is the highest possible estimate (in points) for the $c$-th carriage ( 4 points); $n_{c a r}$ is the number of carriages in the train.

The structure of berths (safety belts on upper level berths) and special facilities for the disabled. The structure of berths (the safety belts on upper level berths) and special facilities for the disabled passengers are evaluated in points as follows: 0 means that the upper level berths are not provided with safety belts and a passenger carriage is not adapted for the disabled passengers, 1 implies that the safety belts are available on the upper level berths, but the carriage is not adapted for the disabled passengers, 2 shows that the upper level berths have safety belts and the carriage is adapted for the disabled passengers, 3 shows that a passenger carriage has only lower level berths (therefore, safety belts are not needed), but it is not adapted for the disabled passengers, 4 means that a passenger carriage has only lower level berths and is adapted for the disabled passengers. The CQI $K_{A}$ summand, assessing the structure of the berths in the carriage (the availability of safety belts on the upper level berths), is calculated by the equation: 


$$
x_{A 9}=\frac{\sum_{c=1}^{n_{c a r}}\left(\frac{P B_{f}}{P B_{\max }}\right)_{c}}{n_{c a r}},
$$

where $x_{A 9}$ is the variable of the 9-th criterion of group $A ; P B_{f}$ is the estimate in points $(0,1$, 2,3 or 4 points) of the berth structure in the $c$-th carriage (the availability of safety belts on the upper level berths) and the adaptation of a passenger carriage for the disabled passengers; $P B_{\max }$ is the highest possible estimate (4 points) of the berth structure (the availability of safety belts on the upper level berths) and the adaptation of a passenger carriage for the disabled passengers; $n_{c a r}$ is the number of carriages in the train.

The availability of regularly operating shower equipment. The availability of shower facilities in a passenger carriage is evaluated in points as follows: 0 means that shower equipment is not installed in the carriage, 1 implies that shower facilities are available in the carriage at fixed hours and are in good working order, 2 shows that shower facilities are available in the carriage at any time. The CQI $K_{A}$ summand, assessing the influence of shower equipment availability in a passenger carriage on travel quality, is calculated by the equation:

$$
x_{A 10}=\frac{\sum_{c=1}^{n_{c a r}}\left(\frac{S_{f}}{S_{\max }}\right)_{c}}{n_{c a r}},
$$

where $x_{A 10}$ is the variable of the 10-th criterion of group A; $S_{f}$ is the estimate of shower equipment availability and its work hours in the $c$-th carriage in points $\left(0,1\right.$ or 2 points); $S_{\max }$ is the highest possible estimate of shower equipment availability and its work hours (2 points); $n_{c a r}$ is the number of carriages in the train.

Special compartments for transporting bicycles. It would be hardly rational to have a special compartment for carrying bicycles in each passenger carriage, therefore, it was considered that there should be at least one railway carriage or a special compartment in the train for bicycle transportation. The possibility of transporting bicycles in the train is evaluated in points as follows: 0 means that there is no special carriage or compartment in the train for carrying bicycles, therefore, their transportation is prohibited, 1 denotes that there is no special carriage or compartment in the train for transporting bicycles, but they may be carried for a fixed payment, when disassembled and packed, 2 implies that there is no special carriage or compartment in the train for transporting bicycles, but they may be carried free of charge, when disassembled and packed, 3 shows that there is a special carriage (or compartment) for transporting bicycles for a fixed payment, 4 means that there is a special carriage (or compartment) for transporting bicycles free of charge. The CQI $K_{A}$ summand, assessing the possibility and conditions of carrying bicycles in the train, is calculated by the equation:

$$
x_{A 11}=\frac{T B_{f}}{T B_{\max }},
$$

where $x_{A 11}$ is the variable of the 11th criterion of group $A ; T B_{f}$ means the presence or absence of a special carriage or compartment for carrying bicycles in the train and the evaluation of 
transportation conditions in points $\left(0,1,2\right.$ or 4 points); $T B_{\max }$ is the highest estimate of the conditions for carrying bicycles in the train (4 points).

Smoking places. This criterion is evaluated in points as follows: 0 means that smoking in the train is prohibited, 1 smoking is allowed in special vestibules, 2 implies that there is a special carriage in the train for smokers. The CQI $K_{A}$ summand, assessing the influence of the conditions for smoking in the train on travel quality, is calculated by the equation:

$$
x_{A 12}=\frac{S P_{f}}{S P_{\max }},
$$

where $x_{A 12}$ is the variable of the 12th criterion of group A; $S P_{f}$ is the estimate of smoking places in the train in points $\left(0,1\right.$ or 2 points); $S P_{\max }$ is the highest possible estimate of smoking places in the train (2 points).

Radio broadcasting unit and its centralized operation (switching on/off). During the trip the information about the route, the names of the stations (the stations, where border and customs control activities are carried out), the arrival of the train at the final station, the information about the services provided, as well as the behaviour rules for passengers in the train and fire safety regulations, which they have to observe in travel, are broadcasted over the radio. Passengers are also informed about the delay of the train, its causes and shortened stopping time because of it. Moreover, radio programmes, as well as popular and classical music, are broadcasted over the radio in the train. A radio broadcasting unit and its centralized operation (switching on/off) are evaluated in points as follows: 0 means that a radio broadcasting unit is not available in the carriage (it is either not installed or is out of order), 1 implies that a radio broadcasting unit in the carriage is switched on or off by a switch located in the conductor's compartment, 2 shows that a radio broadcasting unit in the carriage is switched on or off by switches found in each compartment, 3 denotes that a radio broadcasting unit in the carriage is switched on or off by switches found in each compartment and in the corridor, 4 means that any passenger, who would like to listen to the radio, can use special headphones. The CQI $K_{A}$ summand, assessing a radio broadcasting unit and its centralized on/off switching, is calculated by the equation:

$$
x_{A 13}=\frac{\sum_{c=1}^{n_{c a r}}\left(\frac{R_{f}}{R_{\max }}\right)_{c}}{n_{c a r}},
$$

where $x_{A 13}$ is the variable of the 13 th criterion of group $A ; R_{f}$ is the estimate in points $(0,1,2$, 3 or 4 points) of the operation of the radio broadcasting unit in the $c$-th carriage and its centralized on/off switching; $R_{\max }$ is the highest possible estimate of the radio broadcasting unit operation and centralized on/off switching (4 points); $n_{c a r}$ is the number of carriages in the train.

Dining-car (buffet-car). The availability of the dining car and the provided services and their quality are evaluated in points as follows: 0 means the absence of a dining car in the train, and the conductors of the carriages do not offer any snacks or drinks either, 1 means that there is no dining car in the train, but conductors offer tea, coffee, etc., to passengers, 2 shows that the dining car is available only at weekends, strong drinks are not offered, there 
are no waiters in this car, and conductors do not offer any drinks or snacks to passengers either, 3 means that the dining car is available only at weekends, strong drinks are not offered, there are no waiters in this car, but conductors offer passengers tea, coffee, etc., 4 means that the dining car is available only at weekends, strong drinks are offered there, there is also a waiter in this car, and conductors offer passengers tea, coffee, etc., 5 shows that there is a constantly operating dining car in the train, strong drinks are not offered, there are no waiters there, and conductors do not offer drinks or snacks to passengers either, 6 denotes that there is a constantly operating dining car in the train, strong drinks are not offered, there are no waiters there, but conductors offer tea, coffee, etc. to passengers, 7 means that there is a constantly operating dining car in the train, strong drinks are offered there, but there are no waiters in this car, and conductors offer tea, coffee, etc. to passengers, 8 means that there is a constantly operating dining car in the train, where strong drinks are offered, there is also a waiter there, and conductors offer tea, coffee, etc. to passengers. The CQI $K_{A}$ summand, assessing the influence of the availability of the dining car in the train on travel quality, is calculated by the equation:

$$
x_{A 14}=\frac{D C_{f}}{D C_{\max }},
$$

where $x_{A 14}$ is the variable of the 14 th criterion of group $A ; D C_{f}$ is the estimate of the dining car availability and the provided services in points $\left(0,1,2,3,4,5,6,7\right.$ or 8 points); $D C_{\max }$ is the highest possible estimate of the dining car availability and the provided services (8 points).

The possibility of calling the conductor to a passengers' compartment in emergency cases. It is comfortable for passengers to have an opportunity to call the conductor of a carriage to the compartment, when they need some information or help in the case of emergency. They can do it by pressing a button. The possibility of calling the conductor to a passengers' compartment in the case of emergency is evaluated in points as follows: 0 means that there is no button (switch) for calling the conductor to a passenger's compartment in the carriage, 1 implies that a button (switch) for calling the conductor to a passenger's compartment is installed in every compartment, though it is out of order (e.g. a special magnetic card is required for it to start operating, which is not available); 2 means that a properly operating button (switch) for calling the conductor to the compartment is available in the carriage. The CQI $K_{A}$ summand, assessing the possibility to call the conductor to a passenger compartment in the emergency case, is calculated by the equation:

$$
x_{A 15}=\frac{\sum_{c=1}^{n_{c a r}}\left(\frac{A C_{f}}{A C_{\max }}\right)_{c}}{n_{c a r}},
$$

where $x_{A 15}$ is the variable of the 15 th criterion of group $A ; A C_{f}$ is the estimate in points $(0,1$ or 2 points) of the possibility to call the conductor to a passenger compartment of the $c$-th carriage in the case of emergency; $A C_{\text {max }}$ is the highest possible estimate of the possibility to call the conductor to a passenger compartment in the case of emergency ( 2 points); $n_{c a r}$ is the number of carriages in the train. 
The possibility of using electrical appliances (hairdryer, iron, etc.) in the train. This possibility is estimated in points as follows: 0 means that passengers cannot use a hairdryer, an iron or other electrical appliances in the train, 1 implies that passengers can use their own hairdryers in the train though an iron for ironing clothes is not available, 2 shows that there is a special compartment in the train, where passengers can use a hairdryer and an iron for a fixed payment, 3 means that there is a special compartment in the train, where passengers can use a hairdryer and an iron free of charge, 4 means that there is a beauty parlour, where a passenger can have his/her hair done and a special compartment in the train, where passengers' clothes are washed and ironed free of charge. The CQI $K_{A}$ summand, assessing the possibility of passengers to use a hairdryer and an iron, is calculated by the equation:

$$
x_{A 16}=\frac{H I_{f}}{H I_{\max }},
$$

where $x_{A 16}$ is the variable of the 16th criterion of group $\mathrm{A} ; \mathrm{HI}_{f}$ is the estimate of the possibility for passengers to use a hairdryer and an iron in the train expressed in points $(0,1,2,3$ or 4 points); $H_{\max }$ is the highest estimate of the possibility for passengers to use a hairdryer and an iron in the train (4 points).

The index $K_{A}$, describing the criteria associated with the train elements and railway track condition is calculated by the additive equation:

$$
\begin{aligned}
& K_{A}=\bar{Z}_{A}^{*} \cdot\left[\overline { Q } _ { A 1 } \cdot \left(0.997+0.00245 \cdot T \bar{Q} I_{f}-0.000962 \cdot T \bar{Q} I_{f}^{2}+1.532 \cdot 10^{-5} \cdot T \bar{Q} I_{f}^{3}-\right.\right. \\
& \left.6.99 \cdot 10^{-8} \cdot T \bar{Q} I_{f}^{4}\right)+\bar{Q}_{A 2} \cdot \frac{\sum_{l=1}^{n_{\text {stage }}}\left(1-\frac{\left|\Delta v_{f}\right|}{v_{\max , l}}\right) \cdot l_{l}}{\sum_{l=1}^{n_{\text {stage }}} l_{l}}+\bar{Q}_{A 3} \cdot \frac{\sum_{c=1}^{n_{\text {car }}}\left(\frac{C E S_{f}}{C E S_{\max }}\right)_{c}}{n_{\text {car }}}+ \\
& \bar{Q}_{A 4} \cdot\left(1-\frac{\sum_{c=1}^{n_{c a r}}\left(\frac{N L_{f}}{N L_{\max }}\right)_{c}}{n_{c a r}}\right)+\bar{Q}_{A 5} \cdot \frac{\sum_{c=1}^{n_{c a r}}\left(\frac{C I_{f}}{C I_{\max }}\right)_{c}}{n_{c a r}}+\bar{Q}_{A 6} \cdot \frac{\sum_{c=1}^{n_{c a r}}\left(\frac{V C L_{f}}{V C L_{\max }}\right)_{c}}{n_{c a r}}+
\end{aligned}
$$

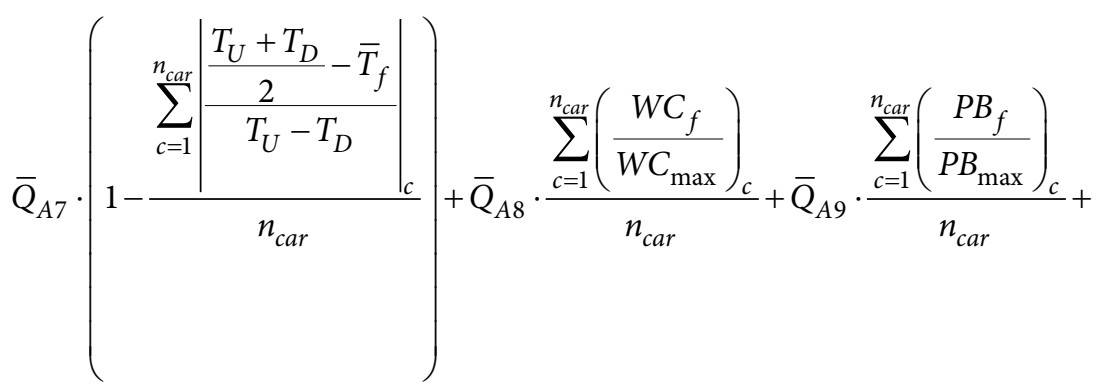




$$
\begin{gathered}
\bar{Q}_{A 10} \cdot \frac{\sum_{c=1}^{n_{c a r}}\left(\frac{S_{f}}{S_{\max }}\right)_{c}}{n_{c a r}}+\bar{Q}_{A 11} \cdot \frac{T B_{f}}{T B_{\max }}+\bar{Q}_{A 12} \cdot \frac{S P_{f}}{S P_{\max }}+\bar{Q}_{A 13} \cdot \frac{\sum_{c=1}^{n_{c a r}}\left(\frac{R_{f}}{R_{\max }}\right)_{c}}{n_{c a r}}+ \\
\left.\bar{Q}_{A 14} \cdot \frac{D C_{f}}{D C_{\max }}+\bar{Q}_{A 15} \cdot \frac{\sum_{c=1}^{n_{c a r}}\left(\frac{A C_{f}}{A C_{\max }}\right)_{c}}{n_{c a r}}+\bar{Q}_{A 16} \cdot \frac{H I_{f}}{H I_{\max }}\right] .
\end{gathered}
$$

Based on the considered model and real research data, as well as the allowable or best values of each criterion, the significance of the criteria of group A for evaluating the quality of passenger transportation by train by a single value may be obtained.

The additive equation (24) was verified by solved example with real data (Sivilevičius, Maskeliūnaite 2014). Consequently the result corresponds the principles of the proposed method for determining the quality of travel by train and is real $\left(K_{A}=0.1341\right.$, i.e. it is $\left.0<K_{A}<1\right)$.

\section{Conclusions}

The quality of travel by train is described by a set of criteria, referring to the parameters of the railway lines, rolling stock (elements of the train) and organization and technology of passenger transportation, as well as the cost and safety of the trip by train. Nineteen out of 49 criteria, making 4 groups and describing the train elements and the technical state of rails (railway track), are considered in the present paper.

The developed original additive mathematical model is used for calculating the values of each of the 16 criteria based on the normalized weight of the criterion multiplied by its variable. The correspondence of the criterion variable to the specified, critical, highest, admissible or the best values is determined. For this purpose, the real (actual) values of the criterion variable are compared with the specified, critical, highest, admissible and the best values, and the value, showing the closeness of a particular criterion describing the trip by train to the best level (when its value is equal to one), average level (when its value is about 0.5 ) and the worst (inadmissible) level (when its value is about 0 ), is calculated.

\section{References}

Bababeik, M.; Monajjem, S. 2012. Optimizing longitudinal alignment in railway with regard to construction and operating costs, Journal of Transportation Engineering 138(11): 1388-1395.

http://dx.doi.org/10.1061/(ASCE)TE.1943-5436.0000448

Burrow, M. P. N.; Naito, S., Evdorides, H. T. 2009. Network-level railway track maintenance management model, Transportation Research Record 2117: 66-76. http://dx.doi.org/10.3141/2117-09

Cherkashin, Yu. M.; Pogorelov, V. A. 2010. Vliyanie parametrov ekipazhey i puti na bezopasnost dvizheniya poezdov, Vestnik VNIIZHT 2: 3-9 (in Russian). 
Dailydka, S. 2010. Choosing railway vehicles for carrying passengers, Transport 25(1): 11-16. http://dx.doi.org/10.3846/transport.2010.02

Darbuotojų apsaugos nuo triukšmo keliamos rizikos nuostatai (patvirtinta Lietuvos Respublikos socialinès apsaugos ir darbo ministro ir Lietuvos Respublikos sveikatos apsaugos ministro $2005 \mathrm{~m}$. balandžio 15 d. i̇sakymu Nr. A1-103 / V-265), Vilnius, 2005 (in Lithuanian).

Daunys, M.; Putnaite, D.; Bazaras, Ž. 2009. Principles for modelling technological processes investigation into the strength and durability of automatic coupler SA-3 in railway carriages, Transport 24(2): 83-92. http://dx.doi.org/10.3846/1648-4142.2009.24.83-92

Dèl didžiausio leistino traukiniu ir lokomotyvu greičio geležinkelio stočių keliais ir tarpstočiais (AB „Lietuvos geležinkeliai“ generalinio direktoriaus 2009 m. lapkričio 3 d. įsakymas Nr. I-843), Vilnius, 2009. 95 p. (in Lithuanian).

Egorov, V. P. 1987. Elektrooborudovanie passazhirskikh vagonov. Moskva: Transport. 312 c. (in Russian).

Estijos prezidentas siūlo Talina ir Vilniu sujungti greituoju traukiniu 2013. BNS, lrytas.lt [online], [cited 20 June 2013]. Available from Internet: http://www.lrytas.lt/ verslas/ener-getika/estijos-prezidentassiulo-talina-ir-vilniu-su-jungti-greituoju-traukiniu.htm (in Lithuanian).

Finichenko, A. Yu. 2011. Normirovanie raskhoda teplovoy energii v prachechnykh, dezinfekcion-nykh kamerakh i na khimchistku rabochey odezhdy v stacionarnom proizvodstve na zheleznodorozhnom transporte, Vestnik VNIIZHT 2: 38-41 (in Russian).

Gorbunov, M. A. 2010. Opredelenie nepreryvnogo raspredeleniya srednikh znacheniy normalnykh napryazheniy v relsakh pod prochodyashim ekipazhem $\mathrm{v}$ pryamykh i krivykh uchastkakh puti, Vestnik VNIIZHT 5: 29-32 (in Russian).

Gould, G.; Niemeier, D. 2009. Review of regional locomotive emission modeling and the constraints posed by activity data, Transportation Research Record 2117:24-32. http://dx.doi.org/10.3141/2117-04

Hamilton, B. A.; Edwards \& Kelcey, J.; ICF Consulting; New Jersey Institute of Technology. 2009. Shared use of railroad infrastructure with noncompliant public transit rail vehicles: a practitioner's guide. Transit cooperative research program (TCRP). Report 130. National Research Council, Washington, D. C.: National Academy Press.110 p.

He, X.-H.; Scanlon, A.; Li, P. 2011. Dynamic factor of bridges subjected to linear induction motor train load, The Baltic Journal of Road and Bridge Engineering 6(3): 185-192. http://dx.doi.org/10.3846/bjrbe.2011.24

Ho, C.; Hyslip, J. P.; Li, D. 2009. Spectral analysis of ground acceleration-based testing, Transportation Research Record 2117: 50-56. http://dx.doi.org/10.3141/2117-07

Ivnitsky, V. A.; Polyakova, M. N. 2011. O koefficiente nadezhnosti zheleznodorozhnogo uchastka, Vestnik VNIIZHT 5: 14-18.

Jafarian, E.; Rezvani, M. A. 2012. Application of fuzzy fault tree analysis for evaluation of railway safety risks: an evaluation of root causes for passenger train derailment, Proceedings of the Institution of Mechanical Engineers, Part F: Journal of Rail and Rapid Transit 226(1): 14-25. http://dx.doi.org/10.1177/0954409711403678

Koc, W. 2012. Design of rail-track geometric systems by satellite measurement, Journal of Transportation Engineering 138(1): 114-122. http://dx.doi.org/10.1061/(ASCE)TE.1943-5436.0000303

Liou, J. J. H.; Tzeng, G.-H. 2012. Comments on "Multiple Criteria Decision Making (MCDM) methods in economics: on overview", Technological and Economic Development of Economy 18(4): 672-695. http://dx.doi.org/10.3846/20294913.2012.753489

Liujiang, K.; Jianjun, W.; Huijun, S. 2012. Using simulated annealing in a bottleneck optimization model at railway stations, Journal of Transportation Engineering 138(11): 1396-1402.

http://dx.doi.org/10.1061/(ASCE)TE.1943-5436.0000450 
Lobo-Guerrero, S.; Vallejo, L. E. 2006. Discrete element method analysis of railtrack ballast degradation during cyclic loading, Granular Matter 8: 195-204. http://dx.doi.org/10.1007/s10035-006-0006-2

Macheret, D. A.; Ryshkov, A. V.; Beloglazov, A. Yu. 2010. Makroekonomicheskaya ocenka razvitiya transportnoy infrastruktury, Vestnik VNIIZHT 5: 3-10 (in Russian).

Makarova, E. A.; Elizarov, S. B.; Muktepavel, S. V. 2011. Avtomatizirovannaya sistema prognozirovaniya passazhirskikh transportnykh potokov na baze ASU 'Ekspress', Vestnik VNIIZHT 4: $21-27$ (in Russian).

Maskeliūnaite, L.; Sivilevičius, H.; Podvezko, V. 2009. Research on the quality of passenger transportation by railway, Transport 24(2): 100-112. http://dx.doi.org/10.3846/1648-4142.2009.24.100-112

Maskeliunaite, L.; Sivilevicius, H. 2011. Applying AHP technique to the assessment of railway trip quality (RTQ), in Proceedings of the 8th International Conference "Environment Engineering": Selected papers, 19-20 May 2011, Vilnius, Lithuania, vol. 3. Ed. by Čygas, D.; Froehner, K. D. Vilnius: Technika, $1133-1141$.

Maskeliūnaite, L.; Sivilevičius, H. 2012. Expert evaluation of criteria describing the quality of travelling by international passenger train: technological, economic and safety perspectives, Technological and Economic Development of Economy 18 (3): 544-566. http://dx.doi.org/10.3846/20294913.2012.710178

Lithuanian Railway. 2012. Metine ataskaita [Annual report]. AB „Lietuvos geležinkeliai“.

Noorzaei, J.; Pour, P. M.; Jaafar, M. S.; Fong, Y. Ch.; Thanoon, W. A.-M. 2012. Numerical simulation of railway track supporting system using finite-infinite and thin layer elements under impulsive loads, Journal of Civil Engineering and Management 18(2): 245-252. http://dx.doi.org/10.3846/13923730.2012.671286

Ramunas, V.; Gailiene, I.; Podagèlis, I. 2011. Increment of railway line capacity, in Proceedings of the 8th International Conference "Environment Engineering": Selected papers, vol. 3. Ed. by Čygas, D.; Froehner, K. D. 19-20 May 2011, Vilnius, Lithuania. Vilnius: Technika, 1193-1199.

Rao, A.; Tsai, T. 2007. Safety standards for high-speed rail transportation, Transportation Research Record 1995: 1-8. http://dx.doi.org/10.3141/1995-05

Saladžius, E. 2012. Geležinkelininkų pajamos - ne tik iš krovinių, bet ir iš naujų idèjų, Lietuvos rytas, 23 November 2012 (in Lithuanian).

Savaeigio kelio matavimo vagono EM-140 matuojamu geležinkelio kelio geometriniu parametrų įvertinimo instrukcija (K/259) (patvirtinta AB „Lietuvos geležinkeliai“ generalinio direktoriaus $2012 \mathrm{~m}$. sausio 4 d. įsakymu Nr. İ-10), Vilnius: UAB „Geležinkelių produkcijos atitikties vertinimo centras“, 2012. 18 p. (in Lithuanian).

Sevi, A.; Ge, L. 2012. Cyclic behaviors of railroad ballast within the parallel gradation scaling framework, Journal of Materials in Civil Engineering 24(7): 797-804. http://dx.doi.org/10.1061/(ASCE)MT.1943-5533.0000460

Sivilevičius, H.; Maskeliūnaite, L. 2010. The criteria for identifying the quality of passengers' transportation by railway and their ranking using AHP method, Transport 25(4): 368-381.

http://dx.doi.org/10.3846/transport.2010.46

Sivilevičius, H.; Maskeliūnaitè, L.; Petkevičienè, B.; Petkevičius, K. 2012. The model of evaluating the criteria, describing the quality of organization and technology of travel by international train, Transport 27(3): 307-319. http://dx.doi.org/10.3846/16484142.2012.724448

Sivilevičius, H.; Maskeliūnaitè, L. 2014. The numerical example for evaluating the criteria describing the quality of the trip by international train, E\& M Ekonomie a Management 12(2): 73-86. http://dx.doi.org/10.15240/tul/001/2014-2-006

Techninio geležinkelių naudojimo nuostatai (patvirtinta Lietuvos Respublikos susisiekimo ministro 1996 m. rugséjo 20 d. įsakymu Nr. 297) 1996. Vilnius: Informacijos ir leidybos centras. 127 p. (in Lithuanian).

Vale, C.; Ribeiro, I. M.; Calcada, R. 2012. Integer programming to optimize tamping in railway tracks as preventive maintenance, Journal of Transportation Engineering 138(1): 123-131.

http://dx.doi.org/10.1061/(ASCE)TE.1943-5436.0000296 
Vorobyev, A. A.; Ivanov, I. A.; Kononov, D. P.; Tarapanov, A. S. 2011. Analiz metodov vosstanovlenija profilia katanija kolesnych par, Vestnik VNIIZHT 3: 34-38 (in Russian).

Walker, W. E.; Baarse, G.; van Velzen, A.; Järvi, T. 2008. Assessing barriers to improving rail interoperability in European countries, Transportation Research Record 2043: 20-30. http://dx.doi.org/10.3141/2043-03

Zakharov, S. M.; Romen, Yu. S. 2010. Matematicheskoe modelirovanie vliyaniya parametrov puti i podvizhnogo sostava na processy iznashivaniya kolesa i relsa, Vestnik VNIIZHT 2: 26-30 (in Russian).

Zakharov, S. M.; Pogorelov, D. Yu.; Simonov, V. A. 2010. Analiz vliyaniya parametrov ekipazhey i puti na intensivnost iznosa $\mathrm{v}$ sisteme koleso - rels (na osnove polnogo faktornogo chislennogo eksperimenta), Vestnik VNIIZHT 2: 31-35 (in Russian).

Zavadskas, E. K.; Turskis, Z.; Tamošaitienė, J. 2010. Risk assessment of construction project, Journal of Civil Engineering and Management 16(1): 33-46. http://dx.doi.org/10.3846/jcem.2010.03

Zhu, Z.-Y.; Ling, X.-Z.; Chen, S.-J.; Zhang, F.; Wang, Z.-Y. 2011. Analysis of dynamic compressive stress induced by passing trains in permafrost subgrade along Qinghai-Tibet railway, Cold Regions Science and Technology 65: 465-473. http://dx.doi.org/10.1016/j.coldregions.2010.10.011

Xu, P.; Sun, Q.; Liu, R.; Wang, F. 2011. A short-range prediction model for track quality index, Proceedings of the Institution of Mechanical Engineers, Part F: Journal of Rail and Rapid Transit 225(3): 277-285. http://dx.doi.org/10.1177/2041301710392477

Lijana MASKELIŪNAITĖ. A doctor, Department of Technological Transport Equipment, Faculty of Transport Engineering, Vilnius Gediminas Technical University. Transport engineer (2006), Department of Technological Transport Equipment, Faculty of Transport Engineering, Vilnius Gediminas Technical University. MSc in transport engineering (2008). Co-author of 9 scientific papers. Several years of experience in passenger transportation by railway: organization of railway passenger trips, provision of services to passengers and the quality of the services provided. Research interests: passenger transportation by railway.

Henrikas SIVILEVIČIUS. Doctor Habil, Professor, Department of Transport Technological Equipment at the Vilnius Gediminas Technical University, Vilnius, Lithuania. A PhD in automobile roads construction (1984) and DrSc (2002) in civil engineering. The author and co-author of more than 180 research papers. Research interests: hot mix asphalt (HMA) production quality and development of quality control methods; statistical and expert methods used in transport system, methods of assessing the state and service life of flexible road pavement. 